\title{
THE LIMITATIONS OF RELIGIOUS PRACTICES IN POLISH PRISONS
}

\author{
Michal Zawislak ${ }^{*}$
}

\begin{abstract}
The subject of this article is the issue of religious fredom of prisoner in the light of limitations of religious practices. The article presents legal and sociological status of religious assistance in contemporary Polish prisons. The aim of the paper is to analyze the prisoner's situation based on selected case law. Religious practices seem to be important part of long process of resocialization of the prisoners, but still prison staff is not prepared to ensure the perform religious practices in right manner. It needs to be stressed that religious practices are subject to limitations in prisons. The article focus on typical problems arising from lack of detailed internal prison policy regulations.
\end{abstract}

Key words: limitation of religious freedom, religious assistance, religious practices, chaplain, prison.

\section{THE SOCIOLOGICAL AND LEGAL BACKGROUND \\ OF THE RELIGIOUS PRACTICES}

Poland is a fine example of a European country where secularization seem to be far away from society and where general religious accommodation in all of its aspects prevails. It is often considered to be one of the most religious societies in highly secularized Europe.

* PhD - Associate Professor, Department of Law on Religion, Faculty of Law, Canon Law and Administration, The John Paul II Catholic University of Lublin. 
According to data from the National Population and Housing Census in 2011, membership in the Roman Catholic Church was declared by $33,728,700$ people, which constitutes $87.6 \%$ of all Polish citizens. ${ }^{1}$

Based on national censuses Poland can be seen as a religious society. The results showed that in terms of ethnic, linguistic and religious diversity Poland is a very homogeneous country. Among the inhabitants of Poland, the majority of the population share a homogeneous Polish national identity $94.8 \%$ of the inhabitants of Poland declared their nationality to be Polish $(36,522,000)$. In 2003 the number of Catholics was estimated at 34,443,998 (90.1\% of the whole population), the number of Orthodox Christians at $510,712(1.34 \%)$ and the number of Protestants at 162,102 (0.42\%) .

More than $90 \%$ of the Poles still consider themselves to be believers. This research has been confirmed by CBOS (Centre of Public Opinion Research) and the Catholic Church Institute of Statistics. According to newest CBOS survey (2015), in 2005 the $58 \%$ declared that they participated in the Holy Mass at least once a week. Currently this proportion amounts to $50 \%$ and the proportion of people who do not attend church has increased from $9 \%$ to $13 \%$. The every-day pray was declared by $66 \%$ of the surveyed in 2005 , and at present $43 \%(2015)^{3}$.

The Church and the State are separated by the Constitution, but the Roman Catholic Church have stronger social position than others religious denominations. In practice this means that presence of the religious symbols (crosses) is visible, and Catholic Church is most vocal and visible among others, but public debate on religious diversity is limited to established religious traditions. The interpretation of national censuses suggests

1 Central Statistical Office. 2015. National-ethnic, linguistic and denominational structure of the Polish population - National Population and Housing Census 2011, 92. Warszawa: CBOS.

2 Michal Czelny, Marta Ordon, Michal Zawiślak, Poland. The Catholic Church's Influence on Social, Political and Private Life. [in:] Religion and Secularism in the European Union. State of Affairs and Current Debates, (eds.) Jan Nelis, Caroline Sagesser, Jean-Philippe Schreiber, Peter Lang 2017, p. 141.

3 Michal Czelny, Marta Ordon, Michal Zawiślak. Poland. The Catholic Church's Influence on Social, Political and Private Life. [in:] Religion and Secularism in the European Union. State of Affairs and Current Debates, (eds.) Jan Nelis, Caroline Sagesser, Jean-Philippe Schreiber, Peter Lang 2017, p. 141. 
that religious belonging become a more popular identity than atheism. At the same time, secularist message critical of right to protect life from natural conception until natural death, financing of in vitro fertilization continue to be voiced, particularly through the media and public protests.

In Poland the right to freedom of religion is protected by the Constitution of 1997 and by the international instruments that have been incorporated into Polish law. Poland is party to most European and universal human rights documents. In the Constitution there is no specific mention of the separation of Church and State. According to the current constitutional regulations, the relationship between the State and Churches and other religious denominations is defined by the following five principles: equality of rights, impartiality, autonomy and independence, cooperation and bilateralism ${ }^{4}$.

The principle of impartiality of public authorities is a general principle of Church-State relations, defines the essence of secularism. The impartiality at issue means an objective attitude, free from bias, characterized by an equal approach to all beliefs which respect the values fundamental to the Polish legal system. Public authorities are clearly obliged to ensure the freedom to express one's convictions in public life. People who perform public functions have a full right to participate in religious celebrations ${ }^{5}$.

Finally, the prominent role of religious traditions in Polish society have been perceived as unproblematic, in some instances even as non-religious. This is for example the case for hanging the crosses in public space ${ }^{6}$. The re-

4 Piotr Stanisz, Religion and Law in Poland, Wolters Kluwer 2017, pp. 34-41; Artur Mezglewski, Henryk Misztal, Piotr Stanisz, Prawo wyznaniowe, 3rd ed., 2011, Warszawa, pp. 75-88; Józef Krukowski, Polskie prawo wyznaniowe, 2005, Warszawa, pp. 52-63; Michał Pietrzak, Prawo wyznaniowe, 2003, Warszawa, pp. 229-233.

5 See Piotr Stanisz, Henryk Misztal, Wolność wyznania a symbole religijne w życiu publicznym „państwa świeckiego”, „Annales Canonici” 2010, t. 6, pp. 37-55; Piotr Stanisz, Relations between the State and Religious Organizations in Contemporary Poland from Legal Perspective, [in:] Neuere Entwicklungen im Religionsrecht europäischer Staaten, (ed.) Wilhelm Rees, María Roca, Balázs Schanda, Wyd. Duncker\&Humblot, Berlin 2013, pp. 687-704.

6 The Polish Sejm emphasized that: "The cross is not only a religious symbol and a token of God's love for people, but in public spaces it is also reminiscent of the readiness to sacrifice oneself for the good of others, and expresses the values shaping respect for the dignity of every human being and his or her rights" Monitor Polski 2009, no. 78, item 962. And Polish Senate in its resolution of 4 February 2010, emphasized that: "Any attempts at banning the cross from schools, hospitals, offices, and public spaces in Poland are to be 
ligious denominations seem satisfied with current situation which statues positive freedom of religion and religious equality. The Catholic Church is object of criticism only when advocate some of political party members. This is a paradox: Catholic Church in many ways allowed in public support for diffrent political candidates because it is perceived as the need of religious values in public morality. This is seen as harmless to people of other religions or beliefs as a promoting one type of „civil religion”. This illustrated clearly that Catholicism is present in society, but when it is found in public it is seen more as cultural heritage than as religious.

\section{THE SCOPE OF RELIGIOUS PRACTICES IN PRISONS}

Pursuant to Article 53 of the Constitution of the Republic of Poland ${ }^{7}$, freedom of conscience and religion shall be ensured to everyone ${ }^{8}$. People staying in prisons and custody suites, including minors staying in similar places, are ensured the right to exercise their freedom of conscience and religion. The following churches are providing their followers with

perceived as harmful to our tradition, history, and national pride". Monitor Polski 2010, no. 7, item 57. See Piotr Stanisz, The Presence of the Cross in Public Spaces in the Context of the Freedom of Thought, Conscience and Religion: A Polish Perspective, [in:] Presence of the Cross in Public Spaces: Experiences of Selected European Countries, (eds.) Piotr Stanisz, Michał Zawiślak, Marta Ordon, Cambridge Scholars Publishing 2016, p. 163-164.

7 Article 53. Para. 1. Freedom of faith and religion shall be ensured to everyone. Para 2. Freedom of religion shall include the freedom to profess or to accept a religion by personal choice as well as to manifest such religion, either individually or collectively, publicly or privately, by worshipping, praying, participating in ceremonies, performing of rites or teaching. Freedom of religion shall also include possession of sanctuaries and other places of worship for the satisfaction of the needs of believers as well as the right of individuals, wherever they may be, to benefit from religious services. Konstytucja Rzeczypospolitej Polskiej z dnia 2 kwietnia 1997 r. Dziennik Ustaw No. 78, item 483 as amended.

8 About the concept of the freedom of religion see: Misztal, Henryk. 1993. Kościelne pojęcie wolności religijnej a ustawa o gwarancjach wolności sumienia i wyznania. Kościół i Prawo 11:104-107; Piechowiak, Marek. 1996. Wolność religijna - aspekty filozoficzne-prawne. Toruński Rocznik Praw Człowieka i Pokoju 3:10-12.

9 The custody suite is a place of temporary isolation for persons suspected of committing a crime, while the prison is a place for serving the sentence of imprisonment. See: Nikołajew, Jerzy. 2012. Wolność sumienia i religii skazanych i tymczasowo skazanych, pp. 50-51. Lublin: Wydawnictwo KUL. 
particular entitlement to enjoy their freedom of religion: Roman Catholic Church $^{10}$, Polish Orthodox Church ${ }^{11}$, Evangelical-Augsburg Church ${ }^{12}$, Polish Reformed Church ${ }^{13}$, Polish Catholic Church ${ }^{14}$, Seventh-Day Adventist Church $^{15}$, Christian Baptist Church ${ }^{16}$, Evangelical Methodist Church ${ }^{17}$, Old Catholic Mariavite Church ${ }^{18}$, Pentecostal Church ${ }^{19}$, Catholic Mariavite Church $^{20}$, and the Union of Jewish Religious Communities ${ }^{21}$.

The provisions of the 17 May 1989 Act on the Guarantees of the Freedom of Conscience and Religion ${ }^{22}$ includes the right for prisoners to

10 Art. 32 Ustawa z dnia 17 maja 1989 r. o stosunku Państwa do Kościoła Katolickiego w Rzeczypospolitej Polskiej, Official Journal 2013 item 1169 as amended.

11 Art. 28 Ustawa z dnia 4 lipca 1991 r. o stosunku Państwa do Polskiego Autokefalicznego Kościoła Prawosławnego w Rzeczypospolitej Polskiej, Official Journal 2014 item 1726.

12 Art. 23 Ustawa z dnia 13 maja 1994 r. o stosunku Państwa do Kościoła Ewangelicko-Augsburskiego w Rzeczypospolitej Polskiej, Official Journal 2015 item 43.

13 Art. 12 Ustawa z dnia 13 maja 1994 r. o stosunku Państwa do Kościoła Ewangelicko-Reformowanego w Rzeczypospolitej Polskiej, Official Journal 2015 item 483.

14 Art. 17 Ustawa z dnia 30 czerwca 1995 r. o stosunku Państwa do Kościoła Polskokatolickiego w Rzeczypospolitej Polskiej, Official Journal 2014 item 1599.

15 Art. 18 Ustawa z dnia 30 czerwca 1995 r. o stosunku Państwa do Kościoła Adwentystów Dnia Siódmego w Rzeczypospolitej Polskiej, Official Journal 2014 item 1889.

16 Art. 18 para. 1 oraz art. 20 ust. 3 Ustawa z dnia 30 czerwca 1995 r. o stosunku Państwa do Kościoła Chrześcijan Baptystów w Rzeczypospolitej Polskiej, Official Journal 2015 item 169.

17 Art. 19 para. 1 Ustawa z dnia 30 czerwca 1995 r. o stosunku Państwa do Kościoła Ewangelicko-Metodystycznego w Rzeczypospolitej Polskiej, Official Journal 2014 item 1712.

18 Art. 16 para. 1 Ustawa z dnia 20 lutego 1997 r. o stosunku Państwa do Kościoła Starokatolickiego Mariawitów w Rzeczypospolitej Polskiej, Official Journal 2015 item 14.

19 Art. 19 para. 1 Ustawa z dnia 20 lutego 1997 r. o stosunku Państwa do Kościoła Zielonoświątkowego w Rzeczypospolitej Polskiej, Official Journal 2015 item 13.

20 Art. 16 Ustawa z dnia 20 lutego 1997 r. o stosunku Państwa do Kościoła Katolickiego Mariawitów w Rzeczypospolitej Polskiej, Official Journal 2015 item 14.

21 Art. 16 Ustawa z dnia 20 lutego 1997 r. o stosunku Państwa do gmin wyznaniowych żydowskich w Rzeczypospolitej Polskiej, Official Journal 2014 item 1798.

22 Article 4 para. 1 point 3 "the right to possess and use the objects required for worshipping and performing religious practices shall also be exercised by persons: (...) staying in prisons, community homes and educational institutes, as well as custody suites and juvenile shelters" and Article 2 item 2 "While exercising their freedom of conscience and belief, the citizens may in particular: participate in religious activities and ceremonies according to the principles of their religion, as well as perform their religious duties and celebrate religious holidays", Official Journal 2005, No. 231, item 1965, as amended. 
perform religious practices. Therefore, every legally recognised religious denomination has the right to provide its followers with pastoral care ${ }^{23}$. Religious denominations should exercise the right to the organisation of pastoral care according to the principle of the equality of religious denominations expressed in Article 25 para 1 of the Constitution of the Republic of Poland ${ }^{24}$.

In practice, regular activities in prisons are conducted by representatives of the following: Catholic Church, Polish Orthodox Church ${ }^{25}$, Evangelical-Augsburg Church $^{26}$, Pentecostal Church, Seventh-Day Adventist Church, Christian Baptist Church, Bible Society, and Jehovah Witnesses ${ }^{27}$. According to the newest data (2017) presented by the Minstry of Justice

23 There are currently 165 registered religious denominations in Poland. Kościoły i związki wyznaniowe wpisane do rejestru kościołów i innych związków wyznaniowych. 2017. https://mswia.gov.pl/pl/wyznania-i-mniejszosci/relacje-panstwa-z-kosci/13964,Relacje-panstwa-z-Kosciolami-przydatne-informacje-dokumenty-i-akty-prawne.html, [date of access 20.04.2017]. See also: Stanisławski, Tadeusz. 2016. Finansowe koszty zapewnienia wolności sumienia i religii osób pozbawionych wolności. [in:] Wolność sumienia i religii osób pozbawionych wolności. Aspekty prawne i praktyczne, (eds.) Jerzy Nikołajew, Konrad Walczuk, pp. 168-169. Warszawa: Wydawnictwo Unitas.

${ }^{24}$ According to the position of the Constitutional Tribunal resulting from the judgment of 2 April 2003 (K. 13/02, OTK -A 2003, No 4, item 28), "the principle of equality of churches and religious denominations shall mean that all churches and religious denominations having a common significant feature should be treated equally. At the same time, this principle assumes different treatment of churches and religious denominations that do not have a common significant feature from the point of view of a given regulation."

25 Migdał, Jerzy. 2008. Polski system penitencjarny w latach 1956-2008 w ujęciu doktrynalnym, normatywnym i funkcjonalnym. Kontynuacja czy zmiana? pp. 390-391. Gdańsk: Arche. In all six dioceses of the Polish Orthodox Church, 47 chaplains perform their service. Lenczewski, Mikołaj. 2016. Posługa duszpasterska kapelanów PAKP w zakładach karnych i aresztach śledczych w Polsce. [in:] Wolność sumienia i religii osób pozbawionych wolności. Aspekty prawne i praktyczne, (eds.) Jerzy Nikołajew, Konrad Walczuk, p. 467. Warszawa: Arche.

26 Migdat, Jerzy. 2008, 390-391. Within the framework of the Evangelical-Augsburg Church, prison chaplains perform their service on the area of four out of six dioceses of this church. Janik, Piotr. 2016. Działalność ewangelickiego duszpasterstwa więziennego w Polsce. [in:] Wolność sumienia i religii osób pozbawionych wolności. Aspekty prawne i praktyczne, (eds.) Jerzy Nikołajew, Konrad Walczuk, p. 484. Warszawa: Wydawnictwo Unitas.

27 Migdał, Jerzy. 2008, pp. 390-391; Niewiadomska, Iwona. 2017. Polski model resocjalizacji penitencjarnej, Teka Komisji Prawniczej. Polska Akademia Nauk Oddział w Lublinie 9:116. 
the following religious denominations are regularly providing the religious assistance in Polish prisons: Roman Catholic Church, Polish Orthodox Church, Evangelical-Augsburg Church, Seventh-Day Adventist Church, Christian Baptist Church, Pentecostal Church, Jehovah's Witnesses, the Bible Society, Greek Catholic Church, Church of Evangelical Faith, Gods Church of Christ, Muslim Religious Community, Buddhist Mission "Three Shelters", and the Union of Jewish Religious Communities ${ }^{28}$.

Pursuant to Article 102 point 3 of the Executive Penal Code of 6 June 1997, people who are imprisoned may exercise their freedom of religion ${ }^{29}$. People beginning their sentence of imprisonment or provisional detention are notified of the possibility of performing religious practices in prison, immediately after their arrival at such an institution. In practice, the first conversation about this subject with a new arrival at a prison / detention centre is held by the prison service officer. It concerns the scope of rights and obligations as well as the internal rules within the scope of performing religious practices and services ${ }^{30}$.

Article $38 \$ 1$ of the Executive Penal Code foresees cooperation with associations, foundations and other organisations, as well as with churches, for the purposes of resocialisation. Moreover, the law allows for the appointment of representatives of churches and religious associations as members of the Rada Gtówna do Spraw Spotecznej Readaptacji i Pomocy Skazanym [General Board for Social Re-integration and Assistance for

28 Odpowiedź na interpelację nr 11980 w sprawie wolności religijnej i edukacji w zakładach karnych i aresztach śledczych [The Statement of the Minstry of Justice on realization of religious freedom and religious education in prisons and detention wards]. [date of access: 10.09 .2017$]$.

29 About the prisoners' right to the freedom of conscience and religion, see inter alia: Malec, Jan. 1989. Posługi religijne w zakładach karnych. Przegląd Penitencjarny i Kryminologiczny (14-15):21-24; Lasocik, Zbigniew. 1993. Praktyki religijne więźniów, Warszawa: Wydawnictwo Naukowe PWN; Bedyński, Krystian. 1994. Duszpasterstwo więzienne w Polsce - zarys historyczny, Warszawa: First Business College; Meler, Sławomir. 2003. Prawo więźniów do wolności religijnej. Przegląd Więziennictwa Polskiego 38:59-67; Duszpasterstwo więzienne w pracy penitencjarnej, (eds.) Jan Świtka, Małgorzata Kuć. 2007. Lublin: Wydawnictwo KUL; Migdał, Jerzy. 2008. Polski system penitencjarny w latach 1956-2008 w ujęciu doktrynalnym, normatywnym i funkcjonalnym. Kontynuacja czy zmiana? Gdańsk: Arche.

30 Nikołajew, Jerzy. 2012, p. 140. 
Convicts $]^{31}$. While staying in prison, prisoners use the charity of religious denominations, such as holiday gift packages, special meetings, and charity concerts ${ }^{32}$, as well as participation in the charity activities of the Catholic Church ${ }^{33}$.

Table 1. Average number of prisoners per one chaplain in 2010

\begin{tabular}{|l|c|c|c|}
\hline Prison ditrict & $\begin{array}{c}\text { Number of prisoners } \\
(2010)\end{array}$ & $\begin{array}{c}\text { Number of chaplains } \\
(2010)\end{array}$ & $\begin{array}{c}\text { Average number } \\
\text { of prisoners per one } \\
\text { chaplain }\end{array}$ \\
\hline Białystok & 3569 & 7,55 & 473 \\
\hline Bydgoszcz & 6771 & 5 & 1354 \\
\hline Gdańsk & 4778 & 6 & 796 \\
\hline Katowice & 7822 & 6,05 & 1293 \\
\hline Koszalin & 4263 & 4,9 & 870 \\
\hline Kraków & 5764 & 4,3 & 1340 \\
\hline Lublin & 4377 & 8,35 & 524 \\
\hline Łódź & 6056 & 3,5 & 1730 \\
\hline Olsztyn & 4777 & 9,75 & 490 \\
\hline Opole & 4467 & 3,55 & 1258 \\
\hline Poznań & 6949 & 3,6 & 1714 \\
\hline Rzeszów & 3771 & 2,2 & 1107 \\
\hline Szczecin & 5039 & 4,55 & 648 \\
\hline Warszawa & 7455 & 11,5 & 1472 \\
\hline Wrocław & 7682 & 5,22 & 971 \\
\hline Total & 83540 & 86,02 & \\
\hline
\end{tabular}

Source: Głowik, Tomasz. 2011. Działalność kościołów i związków wyznaniowych na terenie jednostek penitencjarnych. [in:] Oddziaływanie penitencjarne i terapeutyczne w zakładach karnych i aresztach śledczych w 2010 roku, (ed.) Tomasz Głowik, 104. Warszawa: Centralny Zarząd Służby Więziennej.

31 See: $\$ 2$ para. 4 Rozporządzenia Prezesa Rady Ministrów z dnia 21 sierpnia 1998 r. w sprawie określenia szczegółowych zasad i trybu powoływania oraz działania Rady Głównej do Spraw Społecznej Readaptacji i Pomocy Skazanym, a także rad terenowych do spraw społecznej readaptacji i pomocy skazanym, Official Journal no. 113, item 723.

32 Osowska-Rembecka, Anna. 2016. Programy oddziaływań penitencjarnych na przykładzie Okręgowego Inspektoratu Służby Więziennej w Warszawie. Przegląd Więziennictwa Polskiego 92:134.

33 Osowska-Rembecka, Anna. 2016, p. 143. 
Presented data (table 1) show that polish penitentiary system is not ready to protect religious needs of prisoners. The main problem of penitentiary units is lack of enough number of chaiplains. It is important to note that in 2010 one chaplain was avaible to 971 prisoners. In some districts: Warsaw, Bialystok, Olsztyn, Lublin number of prisoners are less than in other districts which means better acces to chaplain. In other cities: Łódź, Rzeszow, Poznań, the number of prisoners is considerably higher, starting from 1700 to 2000 prisoners per chaplain.

In 2015, a total of 184 chaplains were hired in the prison service, including 28 on a full-time basis (labour contract), mostly Roman Catholic chaplains. The number of jobs for religious assistance is continuously increasing, due to the prevalent number of Catholics in prisons. Chaplains of other religious denominations perform their services both on regular basis paid by the State or free of charge. The number of jobs for nonCatholic chaplains is much smaller (around 33 in total), as the number of prisoners of religions other than Catholic is much smaller ${ }^{34}$.

\section{THE LIMITATIONS TO RELIGIOUS PRACTICES IN POLISH PRISONS - CASE-LAW}

Within the framework of the religious practices of Polish prisoners, the sacramental activity is the most significant ${ }^{35}$. The right to free prayer in a residential cell is the best protected one. Without any obstacles, the religious customs connected with Christmas wafer breaking, the blessing of food on Easter Saturday, participation in rosary services and confession are followed ${ }^{36}$. Prisoners of other faiths can also freely perform religious practices (i.e. ablutions, daily prayer) especially in prison cell. The prison

34 Artur Mezglewski, Finansowanie nauczania religii w placówkach publicznych, [in:] Finansowanie związków wyznaniowych w krajach niemieckojęzycznych i w Polsce, (eds) Dariusz Walencik, Marcin Worbs, Opole 2012, p. 116; T. Stanisławski, Finansowe koszty zapewnienia wolności sumienia i religii osób pozbawionych wolności, [in:] Wolność sumienia i religii osób pozbawionych wolności. Aspekty prawne i praktyczne, (eds) Jerzy Nikołajew, Konrad Walczuk, Warszawa 2016, p. 172.

35 Nikołajew, Jerzy. 2012, p. 385.

36 Nikołajew, Jerzy. 2012, p. 142. 
authorities are using for religious activities among others chapels, viewing rooms, public open rooms, residential cells, rooms for teachers, libraries. The number of chapels is constantly growing, there are currently 130 of them, 55 of which have an ecumenical character ${ }^{37}$.

Individual and collective prayer, as well as participation in services and catechetical meetings organised in prisons, constitute the most available forms of religious activity for prisoners ${ }^{38}$.

Prisoners are allowed to attend services and to listen to them, according to the religion they practise. Every prison has a broadcasting centre, through which radio messages and broadcasts are transmitted, while on Sundays and church holidays the prisoners may listen to Holy Mass ${ }^{39}$. Jews, Muslim and other believers are also allowed to attend religious services. Mostly prisoners of other faiths than Catholics are listening to the catholic radio messages.

Prisoners may freely possess religious objects in their residential cells. In practice, even the stricter standards of conduct used for so-called dangerous prisoners do not limit their possession of these objects. One typical example of these cases is that of a condemned man who, although staying in a highsecurity prison, possessed a Bible, rosary and religious magazines ${ }^{40}$.

37 Głowik, Tomasz. 2011. Działalność kościołów i związków wyznaniowych na terenie jednostek penitencjarnych. [in:] Oddziaływanie penitencjarne i terapeutyczne w zakładach karnych i aresztach śledczych w 2010 roku, (ed.) Tomasz Głowik, pp. 104-106. Warszawa: Centralny Zarząd Służby Więziennej.

38 Meler, Sławomir. 2003. Prawo więźniów do wolności religijnej. Przegląd Więziennictwa Polskiego 38-39:64.

39 About the performance of religious practices in particular prisons: Bielecki, Marek. 2016. Praktyki religijne osadzonych w zakładzie karnym w Zamościu. [in:] Wolność sumienia i religii osób pozbawionych wolności. Aspekty prawne i praktyczne, (eds.) Jerzy Nikołajew, Konrad Walczuk, pp. 403-414. Warszawa: Wydawnictwo Unitas; Wierzbicki, Konrad. 2016. Praktyki religijne osób pozbawionych wolności w zakładzie karnym w Chełmie. [in:] Wolność sumienia i religii osób pozbawionych wolności. Aspekty prawne i praktyczne, (eds.) Jerzy Nikołajew, Konrad Walczuk, pp. 417-431. Warszawa: Wydawnictwo Unitas; Paszkowski, Marek and Justyna Krzywkowska. 2016. Prawo osadzonych do opieki duszpasterskiej i wykonywania praktyk religijnych na przykładzie zakładu karnego w Barczewie. [in:] Wolność sumienia i religii osób pozbawionych wolności. Aspekty prawne i praktyczne, (eds.) Jerzy Nikołajew, Konrad Walczuk, pp. 435-445. Warszawa: Wydawnictwo Unitas.

40 Judgment of the Regional Court in Gliwice of 18 December 2013, II C 131/12, LEX no. 1720749. 
In practice, prisoners have the right to participate in the meetings of various religious groups simultaneosly, and to use the charity provided by them, regardless of their religious affiliation ${ }^{41}$. Each prisoner is able to participate in the meetings of various religious groups even if he/she is not a believer of such religious group. In many prisons there are numerous religious associations, including: Bractwo Więzienne, Towarzystwo Gedeonitów, Chrześcijańskie Stowarzyszenie Pomocy Resocjalizacyjne „Fileo”, Świecki Ruch Misyjny „Epifania”, Ruch Światło-Życie, Odnowa w Duchu Świętym, Stowarzyszenie Rodzin Katolickich, Krucjata Wyzwolenia Człowieka, Apostolstwo Trzeźwości, KARAN - Katolicki Ruch Antynarkotyczny, Towarzystwo Krzewienia Etyki Chrześcijańskiej, Towarzystwo im. Swiętego Brata Alberta, Fundacja Eleos, Stowarzyszenie Katolickie „Legion Maryi”‘2.

In prisons within the Lublin Province, four complaints about religious discrimination were recorded between 1 January 2006 and 30 June 2009. The first one involved a citizen of Belarus staying in the Zaktad Karny Zamość [prison in Zamość district] and concerned the limited right to attend to religious meeting. The second involved a prisoner in the Zaktad Karny Chetm [prison in Chełm district] and concerned the difficult access to a Muslim religious leader. The third involved a prisoner (Polish citizen) who argued that: "members of the Orthodox church and Ukrainians enjoy greater consideration than Poles" because on religious ground. In the fourth case a Russian citizen from Chechnya complained about the non-consideration of his religious food requirements (halal) in the prison in Zamość district ${ }^{43}$. In all the presented cases the complaints were considered to be unfounded by the prison authorities ${ }^{44}$.

One typical case clearly illustrated the problems with understanding of religious needs of prisoners by the prison staff. The prisoner Abd Elsam B. refused to stay in the prison cell because he had to pray face to face

41 Nikołajew, Jerzy. 2012, 167.

42 Tomasz Głowik, Działalność kościołów i związków wyznaniowych na terenie jednostek penitencjarnych, [in:] Oddziaływanie penitencjarne i terapeutyczne w zakładach karnych i aresztach śledczych w 2010 roku, (ed.) Warszawa 2011, pp. 104-106

43 Nikołajew, Jerzy. 2012, p. 174.

44 The report on the method of complaint consideration in the District Prison Service Inspectorate in Lublin in the first six months of the year 2009, July 2009, p. 4. See Nikołajew, Jerzy. 2012, p. 174. 
with the toilet. Then he refused to remove his clothes for religious reasons. $\mathrm{He}$ also demanded the preparation of meals in accordance with religious manner. The director of the detention ward refused his demand because the meals prepared for him would be less healthy than regular meal. It is important to note that detainee has not exercised his right to appeal to the court or to contact the embassy of Egypt ${ }^{45}$. This case shows that there has been an illegal restriction on his religious practices, but for diffrent reasons. Still prison staff seem satisfied with the religious status of catholic prisoners. They can freely perform religious practices, because they are perceived as a believers of a traditional Church which is deeply rooted in cultural heritage. Some religious groups have higher status than others. This inequality in the polish penitentiary system is what we call social stratification. These minority religious groups are often marginalized, but not exluded from society. These groups and individuals are constantly fighting for their rights, for the power to make positive changes for their groups.

The famous case Jakóbski v. Poland clearly describes these observations. In this case, the European Court on Human Rights ruled that Poland violated Article 9 of the Convention due to the lack of preparation of a vegetarian diet for a Buddhist inmate ${ }^{46}$. According to the applicant's religion he was supposed to have a simple meat-free diet. He merely asked to be granted a vegetarian diet, excluding meat products. The Court notes that his meals did not have to be prepared, cooked and served in a prescribed manner, nor did he require any special products. Unlike in the latter case, he was not offered any alternative diet, nor was the Buddhist Mission consulted on the issue of the appropriate $\operatorname{diet}^{47}$. For Catholic prisoners, the preparation of vegetarian meals every Friday and on every religious holiday requiring a fast, i.e. Ash Wednesday and Good Friday, is well ensured.

Considering the number of complaints made by prisoners based on religious discrimination in the years 2012-2014, it shows as follows: in the

45 Nikołajew, Jerzy. 2012, 173.

46 ECHR, Judgment of 7 March 2011, case of Jakóbski v. Poland. (Application no. 18429/06). See Para. 52.

47 Maffei M.C. (2013) The Vegetarian Diet in Prison: A Human Right? The Case of Jakóbski v. Poland. [in:] Boschiero N., Scovazzi T., Pitea C., Ragni C. (eds) International Courts and the Development of International Law. T.M.C. Asser Press, The Hague, The Netherlands pp. 489-496. 
light of total number of complaints 46.231 only two were grounded on religious discrimination and 62 were related to no access of bathing (including religious ablution). In 2013, the total number of recorded complaints was 49.099 only one case was related to religious discrimination, and 61 concerned religious discrimination made by the prison staff. In 2014 the total number of 51.121 complaints were recorded including religious discrimination by prison staff ( 49 cases). The weakness of the Polish penitentiary system is discriminatory treatment of prisoners. Both the prison authorities and other prisoners (Catholics, Protestant) treat the followers of islam with suspicion. It should be noted that in 2017, the Prison Service recorded two requests regarding transport to another penitentiary unit based on religious reasons ${ }^{48}$.

Mostly prisoners complaint about refusal to prepare meals according to religious norms. In one case in 2013 the convicted person failed to respect his right to a religious meal. According to this case, the problem of the possibility of preparing meals by the prisoners themselves from semifinished products has been shown. However, it must be stated, it is necessary to prepare meals according to standard prison norms at all the time.

Another complaint was made by Muslim prisoner who alleged that the regular meals contained pork and that he had no opportunity to eat before and after sunset. He also added that he had no possibility to making ablution of the entire body before each prayer. Pisoner Jacek S. in 2012 alleged that "he could not participate systematically, on every Sunday Mass." Another example was the convicted Michal D., believer of Judaism, who used to eat kosher food from a Jewish restaurant in the city. Anusual situation was recorded in this case, the cost of eating for a year was paid by a Jewish religious community, then by the prison authorities. Finally, the Jewish restaurant resigned to sending food for this prisoner, against his request.

The significant examples of limitation of religious practices of prisoners include the enable of a religious marriage for a detainee. Baptism is also often impossible and always requires the consent of the director of prison

48 Odpowiedź na interpelację nr 11980 w sprawie wolności religijnej i edukacji w zakładach karnych i aresztach śledczych [The Statement of the Minstry of Justice on realization of religious freedom and religious education in prisons and detention wards]. Accesed: 10 September 2017. http://www.sejm.gov.pl/Sejm8.nsf/InterpelacjaTresc.xsp?key=702F36C2 
unit. Prisoners designated as dangerous can participate in the Mass only in their ward. An example of the restriction of religious freedom is the use of chapels for other purposes. Also, the schedule of prison services makes Holy Mass accessible only on spare time of prison authorities. In practice, the prisoners' right to worship is limited, due to the lack of adequate technical measures. Mostly, the limitation of freedom of religion is related to lack of labour contract with the particular religious leader. The official agreement ensuring religious services to Islamic prisoners was signed only in two detention centers (Gdańsk and Bialystok). This means that Islamic prisoners from other prison districts can expect long-term waiting for a religious leader. The biggest problem is the ignorance of Jewish or Muslim holidays by prison staff and other non-Catholic religious customs.

In the case Wojciechowski v. Poland, the European Court ruled that Article 3 of the European Convention on Human Rights (prohibition of torture) was violated in the context of housing conditions; however Article 9 of the Convention was not violated ${ }^{49}$. The complainant argued that as a temporary detainee he had a limited right to participate in the Holy Mass. Evidences in the case indicated that he had the possibility to practise his religion. In 2008, the prison unit where the complainant was staying did not have the capacity to enable all prisoners to participate in collective religious services, so those who wanted to attend had to enrol with their tutor. Their names were then entered into a computer system, selecting participants on a rotating basis.

\section{CONCLUSIONS}

In practice the limitation of religious freedom of prisoners is affected by the lack of knowledge of religious practices, mainly prisoners of Muslims and Jews by prison staff. The prison staff mostly Catholics are not fully understand the needs of religious prisoners of other denominations. Until now none of the religious denominations have questioned the legal framework of religious freedom in Polish prisons. The law provides many

49 ECHR, Judgment of 26 June 2016, case of Janusz Wojciechowski v. Poland (application no. 54511/11). 
opportunities to perform religious practices and fully respects religious pluralism. According to lack of internal prison rules there may be situations where i.e. decision of excluding meet-free diet is taken for reasons other than religious ones. In presented cases the prisons authorities considers that the prisoners decision was not always reasonable. Consequently, the preparation of special meals for only few (one) person would entail too many difficulties of a technical and financial nature. In practice the authorities failed to strike a fair balance between the interests of the prison authorities and those of the prisoners, namely the right to manifest his religion through observance of the rules of their religion.

\section{REFERENCES}

Bedyński, Krystian. 1994. Duszpasterstwo więzienne w Polsce - zarys historyczny, Warszawa: First Business College.

Bielecki, Marek. 2016. Praktyki religijne osadzonych w zakładzie karnym w Zamościu. [in:] Wolność sumienia i religii osób pozbawionych wolności. Aspekty prawne i praktyczne, (eds.) Jerzy Nikołajew, Konrad Walczuk, Warszawa: Wydawnictwo Unitas.

Czelny Michał, Marta Ordon, Michal Zawiślak, 2017. Poland. The Catholic Church's Influence on Social, Political and Private Life. [in:] Religion and Secularism in the European Union. State of Affairs and Current Debates, (eds.) Jan Nelis, Caroline Sagesser, Jean-Philippe Schreiber, Peter Lang.

Duszpasterstwo więzienne w pracy penitencjarnej, (eds.) Jan Świtka, Małgorzata Kuć. 2007. Lublin: Wydawnictwo KUL.

Głowik, Tomasz. 2011. Działalność kościołów i związków wyznaniowych na terenie jednostek penitencjarnych. [in:] Oddziaływanie penitencjarne i terapeutyczne w zakładach karnych i aresztach śledczych w 2010 roku, (ed.) Tomasz Głowik, pp. 104-106. Warszawa: Centralny Zarząd Służby Więziennej.

Janik, Piotr. 2016. Działalność ewangelickiego duszpasterstwa więziennego w Polsce. [in:] Wolność sumienia i religii osób pozbawionych wolności. Aspekty prawne i praktyczne, (eds.) Jerzy Nikołajew, Konrad Walczuk, p. 484. Warszawa: Wydawnictwo Unitas.

Krukowski Józef, 2005. Polskie prawo wyznaniowe, Warszawa.

Lasocik, Zbigniew. 1993. Praktyki religijne więźniów, Warszawa: Wydawnictwo Naukowe PWN. 
Lenczewski, Mikołaj. 2016. Posługa duszpasterska kapelanów PAKP w zakładach karnych i aresztach śledczych w Polsce. [in:] Wolność sumienia i religii osób pozbawionych wolności. Aspekty prawne i praktyczne, (eds.) Jerzy Nikołajew, Konrad Walczuk, Warszawa: Arche.

Malec, Jan. 1989. Posługi religijne w zakładach karnych. Przegląd Penitencjarny i Kryminologiczny (14-15):21-24.

Meler, Sławomir. 2003. Prawo więźniów do wolności religijnej. Przegląd Więziennictwa Polskiego 38:59-67.

Mezglewski Artur, Henryk Misztal, Piotr Stanisz, 2011. Prawo wyznaniowe, 3rd ed., Warszawa.

Migdał, Jerzy. 2008. Polski system penitencjarny w latach 1956-2008 w ujęciu doktrynalnym, normatywnym i funkcjonalnym. Kontynuacja czy zmiana?, Gdańsk: Arche.

Misztal, Henryk. 1993. Kościelne pojęcie wolności religijnej a ustawa o gwarancjach wolności sumienia i wyznania. Kościół i Prawo 11:104-107.

Niewiadomska, Iwona. 2017. Polski model resocjalizacji penitencjarnej, Teka Komisji Prawniczej. Polska Akademia Nauk Oddział w Lublinie 9:116.

Nikołajew, Jerzy. 2012. Wolność sumienia i religii skazanych i tymczasowo skazanych, Lublin: Wydawnictwo KUL.

Osowska-Rembecka, Anna. 2016. Programy oddziaływań penitencjarnych na przykładzie Okręgowego Inspektoratu Służby Więziennej w Warszawie. Przegląd Więziennictwa Polskiego 92:134.

Paszkowski, Marek and Justyna Krzywkowska. 2016. Prawo osadzonych do opieki duszpasterskiej i wykonywania praktyk religijnych na przykładzie zakładu karnego w Barczewie. [in:] Wolność sumienia i religii osób pozbawionych wolności. Aspekty prawne i praktyczne, (eds.) Jerzy Nikołajew, Konrad Walczuk, Warszawa: Wydawnictwo Unitas.

Piechowiak, Marek. 1996. Wolność religijna - aspekty filozoficzne-prawne. Toruński Rocznik Praw Człowieka i Pokoju 3:10-12.

Pietrzak Michał, 2003. Prawo wyznaniowe, Warszawa.

Stanisławski, Tadeusz. 2016. Finansowe koszty zapewnienia wolności sumienia i religii osób pozbawionych wolności. [in:] Wolność sumienia i religii osób pozbawionych wolności. Aspekty prawne i praktyczne, (eds.) Jerzy Nikołajew, Konrad Walczuk, Warszawa: Wydawnictwo Unitas.

Stanisz Piotr, Henryk Misztal, 2010. Wolność wyznania a symbole religijne w życiu publicznym „państwa świeckiego”, „Annales Canonici” 2010, t. 6, pp. 37-55.

Stanisz Piotr. 2017. Religion and Law in Poland, Wolters Kluwer.

Stanisz Piotr, 2013. Relations between the State and Religious Organizations in Contemporary Poland from Legal Perspective, [in:] Neuere Entwicklungen 
im Religionsrecht europäischer Staaten, (ed.) Wilhelm Rees, María Roca, Balázs Schanda, Wyd. Duncker\&Humblot, Berlin.

Stanisz Piotr, 2016. The Presence of the Cross in Public Spaces in the Context of the Freedom of Thought, Conscience and Religion: A Polish Perspective, [in:] Presence of the Cross in Public Spaces: Experiences of Selected European Countries, (eds.) Piotr Stanisz, Michał Zawiślak, Marta Ordon, Cambridge Scholars Publishing.

Wierzbicki, Konrad. 2016. Praktyki religijne osób pozbawionych wolności w zakładzie karnym w Chełmie. [in:] Wolność sumienia i religii osób pozbawionych wolności. Aspekty prawne i praktyczne, (eds.) Jerzy Nikołajew, Konrad Walczuk, Warszawa: Wydawnictwo Unitas. 